\title{
PENERAPAN MEDIA PETA JELAJAH TAMAN BOTANI MATERI BRYOPHYTA DAN PTERIDOPHYTA UNTUK MENINGKATKAN HASIL BELAJAR SISWA SMA MUHAMMADIYAH 01 RAMBIPUJI
}

\author{
1Ita Wahyulia, ${ }^{2}$ Haning Hasbiyati, ${ }^{3}$ Diah Sudiarti \\ 123Pendidikan Biologi, Universitas Islam Jember \\ 1ithawahyulia25@gmail.com,2haninghasbiyati@gmail.com,3diah.sudiarti23@gmail.com,
}

\begin{abstract}
ABSTRAK
Media merupakan salah satu alat bantu yang digunakan oleh guru dalam roses pembelajaran. Masalah dalam penelitian ini adalah hasil belajar siswa rendah, dimana nilai hasil belajar siswa masih banyak yang di bawah KKM, terutama pada saat ulangan harian. Jenis penelitian ini menggunakan PTK, dengan pengumpulan data menggunakan data kuantitatif yang berasal dari tes kognitif hasil belajar siswa. Dengan subyek penelitian sebanyak 18 siswa. Berdasarkan hasil penelitian tersebut rata- rata nilai kognitif siswa pada siklus I sebesar 81. Pada siklus II diperoleh rata-ratanilai kognitif siswa sejumlah 90, maka terjadi peningkatan sejumlah 9\%. Maka penerapan media menggunakan penerapan media Peta Jelajah Taman Botani sangat efektif berasarkan hasil pencapaiaan hasl belajar siswa sehingga dapat membantu dalam keberhasilan proses pembelajaran.
\end{abstract}

Kata kunci: Hasil Belajar, Peta Jelajah, Taman Botani.

\section{ABSTRACT}

Media is one of the tools used by teachers in the learning process. The problem in this study is the low student learning outcomes, where the value of student learning outcomes are still many under the KKM, especially during daily tests. This type of research uses CAR, with data collection using quantitative data derived from cognitive tests of student learning outcomes. With research subjects as many as 18 students. Based on these results, the average cognitive value of students in cycle I was 81 . In cycle II, the average cognitive value of students was 90 , resulting in an increase of $9 \%$. Then the application of media using the application of the Taman Botani roaming media map is very effective based on the results of student learning achievement so that it can help in the success of the learning process.

Keywords: Learning Outcomes, Roaming Maps, Botanical Gardens

\section{PENDAHULUAN}

\section{Latar Belakang}

Ilmu Pengetahuan Alam (IPA) adalah salah satu mata pelajaran yang ada di dalam pendidikan dan juga menjadi salah satu jurusan di sekolah tingkat Sekolah Menengah Atas (SMA). Mata pelajaran IPA mempelajari tentang gejala alam dan proses yang ada di dalamnya serta fenomena dalam kehidupan sehari-hari. Salah satu bagian dari Ilmu Pengetahuan Alam sendiri yaitu Ilmu Biologi. Menurut (Wahyuningsih, 2011) Biologi merupakan salah satu bagian dari ilmu pengetahuan alam (IPA) yang sangat besar pengaruhnya untuk penguasaan ilmu pengetahuan dan teknologi. IPA juga sangat berperan pentingdalam usaha menciptakan manusia yang berkualitas

Berdasarkan hasil wawancara yang telah dilakukan di SMA Muhammadiyah 01 Rambipuji diperolehinformasi bahwa Kriteria Ketuntasan Maksimal (KKM) mata pelajaran IPA yaitu 70, dimana nilai siswa masih banyak yang rendah yaitu sekitar 50\% hasil belajar siswa masih belum tuntas KKM.

Salah satu upayauntukmengatasi permasalahan tersebutadalah dengan 
penggunaan mediayang tepatdalam proses pembelajaran agar materi yang disampaikan ke siswadapat diterimadenganbaik.Salah satu alternatif media yang dapat dimanfaatkan adalah penggunaan Media Peta Jelajah yang berisi gambar tumbuhan serta pengklasifikasiannya. Sehingga lebih menarik agar hasil belajar dapat meningkat.

\section{Rumusan Masalah}

Apakah media Peta Jelajah Taman Botani pada materi Bryophyta dan Pteridophyta dapat meningkatkan hasil belajar siswa kelas $X$ di SMA Muhammadiyah 01 Rambipuji

\section{Tujuan Penelitian}

Untuk mengetahui peningkatan hasil belajar siswa melalui penerapan mediaPeta Jelajah Taman Botani pada materi Bryophyta dan Pteridophyta dapat meningkatkan hasil belajar siswa kelas $X$ di SMA Muhammadiyah 01 Rambipuji

\section{Kajian Pustaka}

a. Hasil Belajar

Hasil belajar adalah prestasi yang di didapat oleh siswa setelah menerima pengalaman pembelajaran yang mempengaruhi perubahan tingkah laku seseorang. Setelah suatu proses belajar berakhir, maka siswa memperoleh suatu hasil belajar. Sedangkan hasil belajar mempunyai peranan penting dalam proses pembelajaran. Menurut Dimyati dan Mudjiono mengutip dari (Zakky:2018) hasil belajar merupakan hasil dari suatu interaksi tindak belajar dan tindak mengajar. Dari sisi guru, tindak mengajar diakhiri dengan proses evaluasi hasil belajar. Dari sisi siswa, hasil belajar merupakan berakhirnya penggal dan puncak proses belajar

b. Media Pembelajaran
Secara umum media merupakan kata jamak dari mediumyang berarti perantara atau pengantar. Istilah media digunakan juga dalam bidang pengajaran atau pendidikan sehingga istilahnya menjadi media pendidikan atau media pembelajaran. Menurut (Yuliza:2018) menyimpulkan bahwa media pembelajaran secara umum adalah seperangkat alat bantu atau pelengkap yang digunakan oleh guru atau pendidik dalam rangka berkomunikasi dengan peserta didik, dibutuhkan oleh pendidik agar pembelajaran berjalan lebih efektif dan efisien

c. Media Peta Jelajah Taman Botani Media Peta Jelajah Taman Botani adalah media yang menggunakan smartphone dalam bentuk peta yang berisi lokasi tumbuhan-tumbuhan yang terdapat di Taman Botani Sukorambi Jember. Penerapan pembelajaran menggunakan media smartphone sesuai dengan hasil observasi dan tes hasil belajar diperoleh bahwa penerapan media pembelajaran berbasis smartphone pada pembelajaran Biologi efektif meningkatkan hasil belajar siswa (Hasbiyati, 2020).

\section{METODE PENELITIAN}

Penelitian ini dilakukan di kelas $X$ SMA Muhammadiyah 01 Rambipuji tahun ajaran 2019/2020 dengan jumlah siswa 18 orang. Penelitian ini dirancang menjadi 2 siklus, dimana pada setiap siklusnya meliputi langkah-langkah perencanaan, pelaksanaan, observasi dan pengumpulan data, dan refleksi.

Setelah mengetahui letak keberhasilan dan hambatan dari pelakasanaan untuk siklus pertama, maka peneliti menentukan rancangan dan mengevaluasi pembelajaran dari siklus pertama untuk proses penelitian di siklus kedua. Fungsi dari penelitian dari siklus 
kedua yaitu untuk lebih meyakinkan dan mengembangkan penelitian pada siklus pertama. Proses pelaksanaan tindakan kedua sama dengan pelaksaan di siklus pertama. Metode pengumpulan data diperoleh dari tes objektif. Tes objektif digunakan dengan tujuan untuk mengetahui hasil belajar siswa selama proses pembelajaran Biologi dalam penerapan media Peta Jelajah Taman Botani.

\section{HASIL DAN PEMBAHASAN}

\section{a. Media Belajar}

Media merupakan salah satu alat bantu yang digunakan oleh guru dalam proses pembelajaran. Penerapan media sendiri tentunya sangat mempengaruhi proses pembelajaran, karena dengan bantuan media pembelajaran dapat membantu pendidik untuk mengkomunikasikan materi dengan tujuan lebih mudah dan efektif. Dari hasil penelitian yang dilakukan tindakan siklus I dan siklus II dihasilkan analisis data nilai hasil belajar siswa mengalami peningkatan dengan menggunakan penerapan media Peta Jelajah Taman Botani berbasis smartphone. Hal tersebut membuktikan bahwa penerapan media juga mempengaruhi peningkatan hasil belajar pada siswa. Karena dengan adanya media, materi yang di sampaikan lebih mudah dipahami oleh siswa dan tidak membuat pembelajaran monoton

Peningkatan hasil belajar siswa menggunakan media Peta Jelajah Taman Botani hasil belajar siswa pada siklus I dengan rata-rata hasil belajar siswa diperoleh nilai 81, sedangkan data hasil belajar siswa pada siklus II diperoleh rata-rata nilai hasil belajar siswa 90 . Hal tersebut sesuai dengan peningkatan hasil belajar siswa dari siklus I ke siklus II dengan peningkatan rata-rata nilai hasil belajar 9\% dengan kriteria semua siswa tuntas dalam memenuhi ketuntasan kriteria maksimal (KKM) 70.

Berdasarkan penelitian tersebut diketahui bahwa nilai rata-rata hasil belajar siswa mengalami peningkatan. Hal tersebut juga di dukung oleh perbandingan hasil belajar siswa prasiklus, siklus I dan siklus II yang dapat dilihat dari grafik 1 berikut ini :

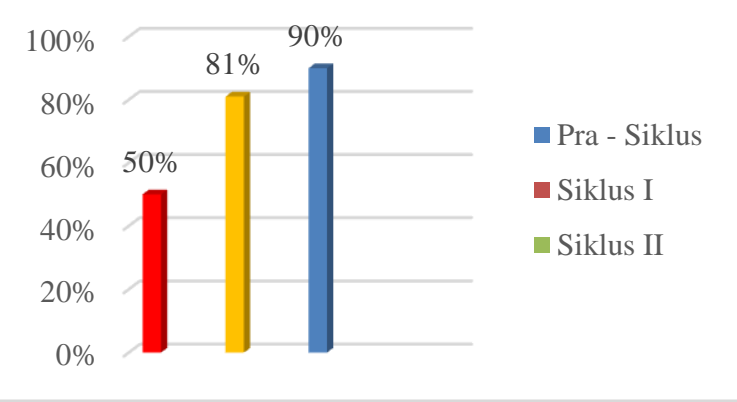

Gambar .1 Grafik Perbandingan Hasil Belajar Siswa

Berdasarkan grafik tersebut dapat dilihat perbandingan hasil belajar siswa pra siklus dengan hasil belajar KKM tuntas sekitar 50\%, sedangkan pada siklus I didapatkan hasil $81 \%$ dan pada siklus II didapatkan hasil $90 \%$, hal tersebut dapat disimpulkan bahwa terjadi peningkatan hasil belajar siswa dengan menggunakan penerapan media Peta Jelajah Taman Botani.

Maka penerapan media Peta Jelajah Taman Botani sangat tepat untuk membantu keberhasilan proses pembelajaran. Hal ini sesuai dengan hasil peningkatan antara siklus I dengan siklus II sebesar 9\%.

Pada media ini menggunakan Peta Jelajah Taman Botani dalam bentuk power point (PPT) berbasis smartphone. Hal tersebut juga di dukung oleh hasil penelitian yang dilakukan, Hasbiyati (2017) dengan judul "E-Book Berekstensi Epub Sebagai Media Pembelajaran Berbasis Smartphone". Di dapatkan hasil tes kognitif berupa gain score pada siklus I dan siklus II meningkat sebesar 0,01 (Hasbiyati, 2017:64). Sedangkan 
dalam penelitian Sianturi (2010:3) tentang perbandingan hasil belajar kimia siswa yang dibelajarkan dengan menggunakan Macromedia Flash, Power Point, dan Peta Konsep pada pokok bahasan hidrokarbon kelas $X$ SMA negeri 3 pematang siantar dapat disimpulkan bahwa pembelajaran dengan media Flash, media Power Point dan Peta Konsep dapat meningkatkan hasil belajar siswa berturut-turut sebesar 63\%, 65\%, dan 50\% (Sianturi,2010:3).

\section{KESIMPULAN}

Pembelajaran melalui media Peta Jelajah Taman Botani dapat meningkatkan hasil belajar siswa pada materi Bryophyta dan Pteridophyta, hal tersebut dapat dibuktikan dengan hasil tes rata-rata nilai kognitif siswa pada siklus I dengan hasil 81 sedangkan pada siklus II mencapai 90, sedangkan pada ketuntasan klasikal pada siklus I mencapai angka 83,3\% dan pada siklus II mencapai angka 100\%. Oleh karena itu peningkatan rata-rata nilai kognitif siswa dari siklus I ke siklus I mengalami peningkatan $9 \%$ dan untuk peningkatan klasikal mencapai $17 \%$.

\section{DAFTAR PUSTAKA}

Aimah, Muslikhatun. 2017. Penggunaan Aplikasi Macromedia Flash 8 Sebagai Media Pembelajaran Interaktif Untuk Meningkatkan Hasil Belajar Siswa. Bioshell Vol.6 No.01 2017

Arikunto. 2010. Prosedur Penelitian: Suatu Pendekatan Praktek. Jakarta: PT. Rineka Cipta.

Arikunto, Suharsimi,et al.2014. Penelitian Tindakan Kelas. Jakarta:PT Bumi Aksara

Bitar.2019.Pengertian Peta.18

Desember 2019.

(www.gurupendidikan.co.id, $\leq 20$ Des ember 2019>)

Burhan.2013.Penelitian Tindakan Kelas. Yogyakarta: Araska.
Daryanto. 2010. Media Pembelajaran. Yogyakarta: Gva Media.

Dimyati,M.2013.Belajar dan Pembelajaran. Jakarta: Rineka Cipta

Djunaidy dan GovernmentTaman Botani Sukorambi .2011. Taman Botani Indonesia.Jember(www.wikipedia.org/wi ki/Taman_Botani_Sukorambi.com, $<16$ Desember 2019>)

Hasbiyati, Haning. 2017. E-Book Berekstensi Epub Sebagai Media Pembelajaran Berbasis Smartphone. Jember: UIJ Kyai Mojo. http://repositori.uij.ac.id/handle/12345 $\underline{6789 / 33}$

Hasbiyati, Haning. 2020. Analisa Efektifitas Penerapan Media Pembelajaran Berbasis Smartphone pada Peningkatan Hasil Belajar Biologi. Jurnal Bio Lectura: Jurnal Pendidikan Biologi.Vol.7.No.1 Hal 10-14

Isnaini, Nur.2015.Komparasi Penggunaan Media Google Earth Dengan Peta Digital Pada Materi Persebaran Fauna Kelas XI IPS di SMA Negeri 1 Semarang.Jurnal Geografi.Vol.12.No.1.Hal.53 dari 114

Komalasari, K.2011.Pembelajaran Konstektual Konsep dan Aplikasi. Bandung: PT.Refika Aditama.

Maimunah. 2016. Metode Penggunaan Media Pembelajaran. Jurnal Al-afkar.Vol.V.No.1 Hal 1-24

PriyayiD.F.2017 Peningkatan Hasil Belajar Koginitif Pada Pembelajaran BiologiSiswa Kelas Xi Ipa 2 SMA Negeri 1 Pabelan Melalui Penerapan Model Project Based Learning

Silaban, Ramlan.,dan Desma Paima Siantun.2011.PengaruhPenggunaan Macromedia Lash, Program Power Point dan Peta Konsep Terhadap Hasil Belajar Kimia Pada Pokok Bahasan Hidrokarbon. Medan:Universitas Negeri Medan

Sudesti, Resti.2013.Penerapan Pembelajaran Berbasis Praktikum Untuk Meningkatkan Penguasaan Konsep dan Keterampilan Proses Sains Siswa SMP Pada Sub Konsep Difusi Osmosis. Skripsi Pendidikan Biologi Universitas Pendidikan Indonesia.Bandung. 
Sulistyorini.ari.2009.BIOLOGI 1.Jakarta: PT. Balai Pustaka

Syukur, sulihin B.2013.Pengaruh Blanded Learning Terhadap Motivasi Belajar dan Hasil Belajar Siswa Tingkat SMA.Jurnal Pendidikan Vokasi,Vol.2.No.3.Hal 368378

Wahyuningsih, A.N.Pengembangan Komik Bergambar Materi Sistem Saraf untuk Pembelajaran yang Menggunakan Strategi PQ4R. Jurnal PP, 2 (1):102-110.

Yuliza, Vivin.2018.Pengembangan Media Pembelajaran Biologi Berbasis Flipchart pada Peserta Didik SMP Kelas VII.Lampung:Universitas Islam Negeri Raden Intan

Zakky.2018.Pengertian Hasil Belajar Siswa dan Definisinya Menurut Para Ahli. (www.zonareferensi.com/pengertianhasil-belajar/, $<26$ November 2019>) 